\title{
BEKERING VAN DIE HEIDEN
}

\author{
PROF. DR. F. J. VAN ZYL
}

\section{Inleiding}

1 (i) Die opskrif hierbo is een van die oudste uitdrukkings om die doel van die missionêre handeling van die kerk in die wêreld aan te dui. Reeds in die sewentiende eeu het Voetius, naas die g l o ri a et manifestatiogratiae divinae en die plan. tatio ecclesiae, die conversiogentium as sendingdoel geformuleer.

1 (ii) Dit gaan in die sendingshandeling van die kerk primêr om die bring van mense tot die geloof in die Drie-Enige God deur die verkondiging van die evangelie van Jesus Christus. So dui die apostel Paulus dan ook die doel van sy roeping aan „om geloofsgehoorsaamheid te verkry onder al die heidene". (Rom. 1:5.) Ons eie kerk praat in sy Kerkwet (Art. 13) onder die "Apostolaat”, van die „evangelisering van die heiden". Dit was veral die piëtistiese sendingsondernemings wat die bekeringsmoment in die sendingdoel baie sterk beklemtoon het. $\mathrm{Al}$ is dit ook so dat die piëtistiese sending die bekering te individualisties beskou het en die koninkryksgedagte verskraal het deur dit te verstaan as die som van individuele bekeerdes, is die "bekering van die heiden" tog altyd as legitieme uitdrukking van die sendingdoel aanvaar.

1 (iii) Vandag word daar ' $n$ redelike groot vraag gestel agter die sinvolle bruikbaarheid van hierdie uitdrukking. Sonder om in besonderhede te tree, kan gestel word dat dit hoofsaaklik aan die invloed van die sekularisasie-teologie en die teologie van die godsdiens te wyte is dat die term: bekering van die heiden, vandag onder verdenking gekom het. Sowel ",heiden” as "bekering” het belaste begrippe geword. Die vraag wat hom nou opdring, is of die uitdrukking, bekering van die heiden, nog gehandhaaf kan word. Wat volg, is 'n poging om bevestigend op daardie vraag te antwoord. Om dit te kan doen, is dit noodsaaklik om elkeen van die begrippe, "heiden" en ",bekering" effens nader te betrag.

\section{Heiden}

2(i) Ons belewe 'n tyd waarin daar by die grootste gedeelte van die wêreld en veral by die sg. derde wêreld 'n verbasende gevoeligheid ontwikkel het teenoor "krenkende" woorde en dade. Die begrip "heiden" is so 'n woord. Die aversie teen die woord is eerstens van etimologiese aard. Die Duitse ekwiwalent van die woord "heiden" is 'n vertaling van die Lateinse $p$ agan us wat op sy beurt naastenby "boslanser" of "bekvelder" beteken. 
Gensichen (Glaube für die Welt, s.107) wys daarop dat Harnack die woord "heiden" in die sin van burger wou verstaan, in teenstelling met die gelowiges as soldate van Christus. Binne die verband van die corpus Christianum het dit in elk geval 'n minderwaardigheid beteken, sowel wat die kulturele en etiese asook die intelektuële vlak betref. 'n Afkeer teen die begrip „heiden" in hierdie $\sin$ is dan ook begryplik.

2 (ii) As 'n mens die ware betekenis van die woord "heiden" wil bepaal, sal daar afgesien moet word van die etimologie, en na die Bybel geluister moet word. Met ander woorde, dis nodig dat ons hierdie woord op sy teologiese kwaliteit moet waardeer. Dan verander die prentjie aanmerklik sodat daar geen sweem van minderwaardigheid meer oorbly nie. Belangriker as die woordonderskeiding - am en gojjim, laos en ethnos - tussen die volk van God en die heiden, is die saaklike betrokkenheid van die twee tot mekaar. Wat die Ou Testamentiese getuienis betref, is dit duidelik dat die besondere bemoeienis van God met Israel wat ' $n$ aanvang neem met die roeping van Abraham, nie net op die uitverkore volk gerig is nie, maar deur hulle op die hele wêreld, al die nasies, die ganse mensheid. Die roeping van Abraham en die volk Israel is die wyse waarop God verder genadiglik handel met die mensheid wat deur die gerig as gevolg van die sondeval by die toring van Babel oor die aarde verstrooi is. Soos wat die volk van God deur die genadige verkiesingsdaad van sy Skepper in aansyn geroep word, so kry die nasies, die heidene, buite hierdie verbond, tog ' $n$ besondere bestaan omdat dit vir God in die verkiesing van sy eiendomsvolk juis te doen is om al die nasies van die wêreld. Ons kan dus sê dat die heidene, die nasies, tevoorskyn tree met die ontstaan van die volk van God. Anders gesê: die verkiesing van Israel en God se handeling met hierdie volk, is tegelyk sy bekendmaking, deur hierdie partikuliere handeling, aan die wêreld rondom hierdie volk. Nog anders gesê: die openbaring van God in sy geskiedenis met die volk Israel, is ook op die heiden gerig, bring hom as't ware as voorwerp van God se bemoeiing tevoorskyn. Wat daar anders ook van die heiden gesê mag word, moet hierdie positiewe eerste en as die belangrikste gesê word, dat God se openbaring op hom gerig is. In hierdie lig moet ons die uitspraak van Paulus ook verstaan dat God nie ver is van elkeen van ons nie, en dat Hy God is ook van die heidene.

2(iii) Die lyn van positiewe betrekking tussen openbaring en heiden, word van die Ou Testament ook na die Nuwe Testament baie duidelik deurgetrek. Hier is veral sekere uitsprake van die apostel Paulus in Rom. 1 en 2 belangrik. Daar word gepraat van „Wat van God geken kan word, in hulle openbaar is, want God het dit aan hulle openbaar. Want sy onsigbare dinge kan van die 
skepping van die wêreld af in sy werke verstaan en duidelik gesien word ..." (Rom. 1:19, 20.) „Want wanneer die heidene wat geen wet het nie, van nature die dinge van die wet doen, is hulle vir hulleself ' $n$ wet, al het hulle geen wet nie; omdat hulle toon dat die werke van die wet in hulle harte geskrywe staan, terwyl hulle gewete saam getuienis gee..." (Rom. 2:14, 15.) Van hierdie uitsprake moet nie te veel gemaak word nie. Daaruit kan geen algemene, natuurlike godskennis, geen grond vir 'n aanknopingspunt of „.vorverständnis", geen kontinuitteit tussen heidendom en die reddende gosdkennis afgelei word nie. Sulke moontlikhede word afgesny deur die onomstootlike getuienis dat hulle ondanks die openbaring, God tog nie verheerlik en gedank het nie. Ook uit die feit dat "hulle toon dat die werk van die wet in hulle harte geskrywe staan", moet nie oorhaastige konklusies getrek word nie. Paulus se hele betoog is juis daarop gerig dat die werke van die wet geen mens, Jood of heiden kan regverdig nie. Aan die ander kant moet ook nie weer te min van hierdie uitsprake gemaak word nie. Hulle is in soverre belangrik dat hulle alle pogings om ' $n$ totale diskontinuiteit tussen God en die heiden te handhaaf, by die grond afsny. Paulus sê nee tot beide, kontinuiteit en diskontinuïteit. Nee tot die eerste is nodig omdat daar geen ongebroke kontinuiteit tussen God en mens, godskennis en heidense godsdiens bestaan nie. Nee tot die tweede is egter ook nodig, sodat die mens hom nie met ' $n$ vlug in sy heidendom sou kon verontskuldig nie. Omdat die heiden in die lig van God se openbaring is wat hy is, staan hy altyd, ook in sy afgodediens in betrekking tot God, omdat God hom ook in die oog gehad het toe Hy sy Seun vir die wêreld gegee het. Die mens kan van God wegvlug, maar hy kan Hom nooit ontvlug nie. As 'n mens die uitdrukking: bekering van die heiden, wil behou, is dit voor alles dus nodig dat die "heiden" in sy teologiese betekenis reg begryp word.

\section{Bekering}

3(i) Reeds is die aandag daarop gevestig dat ook en miskien veral, die woord „,bekering" ons voor 'n erg belaste saak stel. Die bedoeling is nie om negatief te vertoef by die emosionele en sinergistiese klem wat dit soms dra by 'n meer piëtisties georiënteerde denke nie, maar om positief een-en-ander oor enkele aspekte van die saak te sê.

3(ii) Daar moet ' $n$ baie noue betrekking tussen geloof en bekering aanvaar word. Eintlik moet die betrekking ook na die wedergeboorte uitgebrei word. As 'n mens die geloof verstaan as die wyse waarop die Heilige Gees die relasie bewerk tussen die mens en Christus sodat die heilswerk op hierdie wyse aan die mens toegeëien word, dan beteken hierdie nuwe en noue betrekking tot die opgestane Christus ' $n$ deel kry aan die versoening wat op Golgota bewerk 
is. Deur die geloof is die gelowige in Christus. Daardeur het hy 'n nuwe skepsel geword. (2 Kor. 5:17.) Die wedergeboorte wil dit onderstreep dat ' $n$ gelowige in Christus nuut gebore is, dat hy ' $n$ nuwe skepsel geword het. Die bekering wil die feit onderstreep dat die gelowige ' $n$ lewende mens is, dat geloof ' $n$ saak is wat die mens in sy diepste wese tref. As daar deur die geloof in Christus 'n nuwe lewe in hom begin het, moet dit ook in sy lewe, sy handel en wandel blyk, want die gelowige is geen stok en blok nie. 'n Mens kan dus sê dat bekering die wyse is waarop die geloof in die lewe van die gelowige tot uiting kom.

3(iii) Uit die voorgaande vloei enkele konklusies.

3(iii) (a) Daar is geen bekering moontlik sonder kennis van die evangelie nie. Dit moet gesê word op grond van die noue verband tussen geloof en bekering. Trouens, bekering, soos ons gesien het, is die wyse waarop die geloof tot uiting kom. Daar is maar net een manier waarop die geloof in 'n mens gewek word, $\mathrm{nl}$. deur die prediking van die evangelie. (Rom. 10:17.) Hierdie geloof wat deur die hoor van die verkondigde evangelie gewek word, kom deur die bekering tot uiting in die lewe en wel as ' $n$ op God gerigte lewe en juis daarom 'n mensgerigte lewe, want God is ' $n$ God vir die wêreld.

3 (iii) (b) Soos die geloof, net so is ook die bekering geen menslike prestasie nie. Geloof is die wyse waarop die Heilige Gees, d.w.s. waarop God self die versoeningswerk van Christus aan ons toeëien, die wyse waarop God wat sorg vir ons heil, dit ook aan ons besorg. Geloof is in God se regverdigende handeling met die mens ingesluit. Dit is dus ' $n$ gawe van God, geen verdienste of prestasie van die mens nie. Wat die aktuele verwerkliking van die geloof betref, is dit deur-en-deur ' $n$ menslike aangeleentheid, hoewel dit nooit ' $n$ menslike moontlikheid is nie. Dit alles geld onverkort net so van die bekering. Geen mens kan homself bekeer nie, net so $\min$ as wat hy uit eie krag kan glo. Geen mens kan ook 'n ander bekeer nie, dit kan God alleen deur die werking van die Heilige Gees doen.

3(iii) (c) Sowel wat die geloof as wat die bekering betref, werk die Heilige Gees nooit onmiddellik nie. Die Gees maak gebruik van een instrument om geloof/bekering te bewerk, $\mathrm{nl}$. die prediking van die evangelie van Jesus Christus. Wanneer mense deur die prediking van die getuienis van apostels en profete wat die opgestane Heer gesien het, God in sy ondeurgrondelike liefde vir sondaars só leer ken dat hulle hulle lewe sonder reserwes met vertroue in sy hand lê, dan glo hulle en daardie geloof kom tot uiting as bekering in ' $n$ lewe van dankbaarheid en blydskap in diens van God en medemens. Die versoening wat op Golgota vir die hele wêreld volbring is. 
beteken nie dat alle mense nou aktueel versoen is en gelowiges geword het nie. Die aktuele toeëiening van die versoening geskied alleen deur die diens, die prediking, van daardie versoening. Die nuwe lewe deur die versoening op Golgota moet telkens opnuut in die bekering deurbreek deurdat mense die verkondigde evangelie van die versoening glo. Die persoonlike moment in die bekering kan derhalwe nooit uitgesluit word nie. Vir sommige mense kan die moment van bekering as gevolg van allerlei ervaringe wat daarmee gepaard gaan 'n baie uitstaande gebeurtenis wees sodat dag en datum onvergeetlik bly. Dit kan ook sonder enige noemenswaardige gevoelens geskied wat ' $n$ mens verras deur die onopsigtelikheid en die byna alledaagsheid waarmee die nuwe lewe van die geloof in die bekering tot uiting gekom het.

3(iii) (d) Geloof en bekering, die ganse wonder van die nuwe skepsel, beteken ' $n$ bepaaldheid van die mens in sy totaliteit. In hierdie verband is die vernuwing van die gewete baie belangrik. Die gewete en die daadwerklike uiting van die geloof in 'n nuwe lewe staan in noue verband met mekaar. Dit blyk veral ook duidelik uit die derde aspek van die voorbereiding tot die heilige nagmaal waar die eis gestel word dat „elkeen sy gewete (moet) ondersoek of hy ook gesind is om voortaan met sy ganse lewe dankbaarheid jeens God die Heer te bewys en voor die aangesig van God opreg te wandel, ook of hy sonder enige geveinsdheid alle vyandskap, haat en nyd van harte wil aflê, en 'n ernstige voorneme het om van nou af in waaragtige liefde en eensgesindheid met sy naaste te lewe". Die klem val dus by die gewetensondersoek op die lewe van dankbaarheid onder die gebod van God. Gewete beteken saamweet. In die geval van 'n gelowige beteken dit die saamweet met God. Anders gestel, die gelowige mens word onder die Woord en die gebod van God gestel. Hy word 'n geroepene van God. Die vernuwing van sy gewete beteken juis dat sy lewe nou onder hierdie woord en wet van God gestel word en wat in die bekering deurbreek as ' $n$ nuwe lewe in gehoorsaamheid aan God. Bekering beteken dan deurbreek van die nuwe lewe in Christus. In die geval van ' $n$,"heiden" moet dit noodwendig met ' $n$ breek met allerlei vorige verbintenisse en lojaliteite gepaard gaan. Dit beteken nie net 'n nuwe denke oor die lewe nie, maar ' $n$ afkeer van 'n ou lewe en 'n toekeer tot 'n nuwe waarin ' $n$ mens vry geword het van eie begeertes en hartstogte tot die ware vryheid in gebondenheid aan God se Woord en wet. Dit moet noodwendig ook ' $n$ verandering in godsdiens ten gevolg hê.

\section{Konklusie}

Uit die voorgaande paragrawe het dit duidelik geword dat geloof en bekering sake is wat in die diepste geheimenisse van die Gees gegrond is. ' $n$ Mens kan dit slegs as wondergawes van die 
Gees verstaan en waardeer. Daarom is daar ook geen vaste bekeringsformule nie. ' $n$ Mens kan jou alleen daaroor verwonder dat mense nog gelowig word en bekeerd raak ondanks die feit dat ons verkondiging van die evangelie so gebrekkig is en ondanks die feit dat die hoor van daardie verkondiging net so gebrekkig is. In hierdie sin, nl. dat "heidene", maar dan "heiden" in sy teologiese betekenis, deur die verkondiging van die evangelie gelowig word en dat daardie geloof in 'n nuwe lewe deurbreek, is die uitdrukking: bekering van die heiden, nog altyd sinvol en bruikbaar. Die missionêre verkondiging van die kerk vind plaas sodat die wonder van geloof en bekering kan geskied. Ewe wonderlik is dit dat die wonder wat God wil laat gebeur, deur gebruikmaking van swakke en gebrekkige menslike getuienis geskied. 